\title{
Regulation of Glutamate Transport in Developing Rat Oligodendrocytes
}

\author{
Tara M. DeSilva, Anatoli Y. Kabakov, Patricia E. Goldhoff, Joseph J. Volpe, and Paul A. Rosenberg \\ Department of Neurology and F. M. Kirby Neurobiology Center, Children's Hospital and Harvard Medical School, Boston, Massachusetts 02115
}

Glutamate released from synaptic vesicles mediates excitatory neurotransmission by stimulating glutamate receptors. Glutamate transporters maintain low synaptic glutamate levels critical for this process, a role primarily attributed to astrocytes. Recently, vesicular release of glutamate from unmyelinated axons in the rat corpus callosum has been shown to elicit AMPA receptor-mediated currents in glial progenitor cells. Glutamate transporters are the only mechanism of glutamate clearance, yet very little is known about the role of glutamate transporters in normal development of oligodendrocytes (OLs) or in excitotoxic injury to OLs. We found that OLs in culture are capable of sodium-dependent glutamate uptake with a $K_{\mathrm{m}}$ of $10 \pm 2 \mu \mathrm{m}$ and a $V_{\max }$ of $2.6,5.0$, and $3.8 \mathrm{nmol} \cdot \mathrm{min}^{-1} \cdot \mathrm{mg}^{-1}$ for preoligodendrocytes, immature, and mature OLs, respectively. Surprisingly, EAAC1, thought to be exclusively a neuronal transporter, contributes more to $\left[{ }^{3} \mathrm{H}\right.$ L-glutamate uptake in OLs than GLT1 or GLAST. These data suggest that glutamate transporters on oligodendrocytes may serve a critical role in maintaining glutamate homeostasis at a time when unmyelinated callosal axons are engaging in glutamatergic signaling with glial progenitors. Furthermore, GLT1 was significantly increased in cultured mature OLs contrary to in vivo data in which we have shown that, although GLT1 is present on developing OLs when unmyelinated axons are prevalent in the developing rat corpus callosum, after myelination, GLT1 is not expressed on mature OLs. The absence of GLT1 in mature OLs in the rat corpus callosum and its presence in mature rat cultured OLs may indicate that a signaling process in vivo is not activated in vitro.

\section{Introduction}

Glutamate is the major excitatory neurotransmitter in the brain and underlies many aspects of brain function and development. Glutamate exerts its role by stimulating glutamate receptors. Glutamate transport is the only mechanism responsible for clearance of excitatory amino acids. The glutamate transporter family has five subtypes, known as EAAT1-EAAT5 in humans; EAAT1EAAT3 are recognized as GLAST, GLT1, and EAAC1, respectively, in rodents (Pines et al., 1992; Storck et al., 1992; Arriza et al., 1994, 1997; Fairman et al., 1995).

Our studies in human cerebral white matter showed that GLT1 is expressed in oligodendrocytes (OLs) during development and is not found in astrocytes until postnatal development (DeSilva et al., 2007, 2008). Many lines of evidence suggest that glutamate regulation by oligodendrocytes may serve a critical function in developing cerebral white matter. First, AMPA and NMDA receptors are expressed on OLs (Patneau et al., 1994; Puchalski et al., 1994; Gallo and Russell, 1995; Yoshioka et al., 1995; Meucci et al., 1996; Follett et al., 2000; Káradóttir et al., 2005; Salter and Fern, 2005; Micu et al., 2006; Talos et al., 2006a), the same receptors known to mediate glutamatergic signaling in neurons. Second, there are multiple possible sources of glutamate

Received Dec. 22, 2008; revised March 16, 2009; accepted April 8, 2009.

This work was funded by National Institutes of Health Grants NS41883, NS40753, NS38475, and HD18655, the United Cerebral Palsy Foundation, the Hearst Foundation, and the Association Européenne contre les Leucodystrophies. We thank Peter Dikkes for his expert advice on histology.

Correspondence should be addressed to Paul A. Rosenberg, Center for Life Sciences 13073, Department of Neurology, Children's Hospital, 300 Longwood Avenue, Boston, MA 02115. E-mail: paul.rosenberg@childrens.harvard.edu. DOl:10.1523/JNEUROSCI.6129-08.2009

Copyright $\odot 2009$ Society for Neuroscience $\quad$ 0270-6474/09/297898-11\$15.00/0 during development such as vesicular release of glutamate from unmyelinated axons (Ziskin et al., 2007) and from astrocytes mediated by chemokines (Bezzi et al., 2001), prostaglandins (Bezzi et al., 1998), and neuropeptides (Parpura et al., 1994). Also, glutamate has been shown to stimulate oligodendrocyte progenitor migration, proliferation, and differentiation (Gallo et al., 1996; Yuan et al., 1998; Gudz et al., 2006). Finally, we have shown that, in developing human cerebral white matter, glutamate transporters are present on OLs (DeSilva et al., 2007, 2008) at a time when glutamate receptors are expressed (Talos et al., 2006a,b). To further explore the regulation and function of glutamate transporters on OLs, studies were undertaken in cultured OLs from rat forebrain in combination with expression profile studies in the rat corpus callosum.

Here, we demonstrated that cultured rat OLs have a similar uptake capacity and affinity for glutamate compared with astrocytes (Garlin et al., 1995; Swanson et al., 1997; Schlag et al., 1998) and, surprisingly, that EAAC1 was responsible for most of the glutamate uptake. The expression profile of GLT1 in cultured rat OLs was different than that in the human in vivo, in which GLT1 was found to be expressed in developing OLs but not in mature myelin basic protein expressing OLs. We investigated the issue of expression of GLT1 in mature OLs in the rat corpus callosum and found that, in this species as well, GLT1 was downregulated. The in vitro findings taken together with the in vivo findings suggest a potential role for cell signaling in regulating GLT1 expression during myelination. In addition, these data support the hypothesis that glutamate transport by OLs maintains glutamate homeostasis in developing cerebral white matter. 
Table 1. Glutamate transporter contribution to glutamate uptake in oligodendrocytes and neurons

\begin{tabular}{lllr}
\hline Cell type & GLT1 & EAAC1 & GLAST \\
\hline $\begin{array}{llll}\text { Proeligodendro- } \\
\quad \text { cytes }\end{array}$ & & \\
Mature 0Ls & $22 \%$ & $53 \%$ & $25 \%$ \\
Neurons & $27 \%$ & $48 \%$ & $25 \%$ \\
\hline
\end{tabular}

\section{Materials and Methods}

Animals. Three litters of rat pups were obtained from timed pregnant Long-Evans rats (Charles River Laboratories). Each litter was delivered on a different date and allowed to grow postnatally according to the protocol of the Institutional Animal Care and Use Committee. The following time points were used: postnatal day 1 (P1), P3, P7, P20, P30, and $\mathrm{P} 60$ with at least three rats for each time point. The rats for P30 and P60 were ordered at their respective ages.

Perfusion and cryoprotection of rat brains. Rats were anesthetized with 100 $\mathrm{mg} / \mathrm{kg}$ of $50 \mathrm{mg} / \mathrm{ml}$ sodium pentobarbital before transcardiac perfusion with $4 \%$ paraformaldehyde. Briefly, a needle was inserted into the left ventricle, the right atrium was cut, and PBS was slowly pumped through the heart (1.5 mM potassium dihydrophosphate, $2.7 \mathrm{~mm}$ sodium phosphate, and $150 \mathrm{~mm}$ sodium chloride, $\mathrm{pH}, 7.4)$. Once the liver cleared, the rat was perfused with $4 \%$ paraformaldehyde. The ratio of volumes of PBS to paraformaldehyde perfused into the animal was 1:1.5, with the starting volume depending on the initial weight of the rat. Brains were postfixed in $4 \%$ paraformaldehyde for $24 \mathrm{~h}$ and subsequently cryoprotected in PBS containing $30 \%$ sucrose and stored at $-80^{\circ} \mathrm{C}$. The brains were embedded in OCT embedding medium, cut $(20 \mu \mathrm{m})$ sagittally on a cryostat, and mounted on Superfrost Plus slides (Thermo Fisher Scientific).

Antibodies for Western blot analysis and immunocytochemistry. A polyclonal antibody against the N terminus of GLT1 (anti-nGLT1), which detects both variant forms of GLT1, GLT1a and GLT1b, was generated in New Zealand White rabbits (Research Genetics) and characterized previously (Chen et al., 2002, 2004). This antibody was generated based on the published sequences for rat GLT1a and GLT1b (amino acids 1-15; GenBank accession number AF451299). A polyclonal antibody against the $\mathrm{C}$ terminus of GLT1a was generously provided by Dr. J. Rothstein (Johns Hopkins University, Baltimore, MD). The specificity of this antibody has been characterized previously (Rothstein et al., 1994; Chen et al., 2002, 2004) and was generated based on the published sequence for rat (amino acids 559-573; GenBank accession number AF451299). Polyclonal antibodies against the C-terminal peptide corresponding to the last 15 aa (amino acids 548-562) of rat GLT1b were generated in New Zealand White rabbits (Research Genetics) and characterized previously using rat brain tissue, rat forebrain neurons in culture, and COS7 cells expressing rat GLT1a and GLT1b cDNA (Chen et al., 2002, 2004). A polyclonal antibody against the $\mathrm{C}$ terminus of EAAC1 (amino acids 455524) was obtained commercially (Santa Cruz Biotechnology). To determine the specific cell types in which glutamate transporters are located, the following antibodies were used for double-labeled immunocytochemistry: A2B5 monoclonal antibody was obtained from cells provided by the American Type Culture Collection; $\mathrm{O} 4$ and $\mathrm{O} 1$ monoclonal antibodies were obtained from cells that were a generous gift from Dr. Stephen Pfeiffer (University of Connecticut Health Science Center, Farmington, CT); anti-myelin basic protein (MBP) marker SMI-99 was used to identify mature OLs (Sternberger Monoclonals); neurofilament marker SMI 312 (Sternberger Monoclonals) was used to detect axons.

Cultured oligodendrocytes. OLs were cultured based on previously published methods for producing highly enriched, stage-specific cultures ( $\mathrm{Li}$ et al., 2003; Rosenberg et al., 2003) and generally followed the procedures developed by McCarthy and colleagues (McCarthy and de Vellis, 1980; Espinosa de los Monteros et al., 1997) and Gard et al. (1993). PreOLs were cultured for $7 \mathrm{~d}$ in basal defined media (DMEM containing $25 \mathrm{~mm}$ glucose, $4 \mathrm{~mm}$ L-glutamine, $1 \mathrm{~mm}$ sodium pyruvate, $50 \mathrm{mg} / \mathrm{ml}$ human apo-transferrin, $5 \mathrm{mg} / \mathrm{ml}$ bovine pancreatic insulin, $30 \mathrm{~nm}$ sodium selenium, $10 \mathrm{~nm}$ hydrocortisone, $10 \mathrm{~nm}$ D-biotin, and $1 \mathrm{mg} / \mathrm{ml} \mathrm{BSA}$ ) supple-
Table 2. $K_{\mathrm{i}}$ values for competitive antagonists for the respective glutamate transporter

\begin{tabular}{lllllll}
\hline & TBOA & \multicolumn{5}{l}{ DHK } \\
\hline Transporter & EAAC1 & GLT1 & GLAST & EAAC1 & GLT1 & GLAST \\
$K_{\mathrm{i}}(\mu \mathrm{M})$ & 6 & 6 & 70 & 1000 & 8 & $>3000$
\end{tabular}

$K_{\mathrm{i}}$ values of DHK: for EAAC1, Dowd and Robinson, 1996; Davis et al., 1998; GLT1, Wang et al., 1998; and GLAST, Arriza et al., 1994. $K_{\mathrm{i}}$ values of TBOA: Shimamoto et al., 1998; Bridges et al., 1999.

mented with recombinant basic fibroblast growth factor (bFGF) (10 ng/ $\mathrm{ml}$ ) and human platelet derived growth factor (PDGF) $(10 \mathrm{ng} / \mathrm{ml})$. Immature OLs were cultured for $14 \mathrm{~d}$ in basal defined medium (BDM) containing PDGF (10 ng/ml), forskolin (30 nM), neurotrophin-3 (10 $\mathrm{ng} / \mathrm{ml}), \mathrm{T} 3(3 \mathrm{ng} / \mathrm{ml})$, and ciliary neurotrophic factor (CNTF) (10 ng/ $\mathrm{ml})$. Mature OLs were cultured for $7 \mathrm{~d}$ in BDM containing the growth factors bFGF (10 ng/ml) and PDGF $10 \mathrm{ng} / \mathrm{ml})$, followed by another $7 \mathrm{~d}$ in BDM containing T3 $(3 \mathrm{ng} / \mathrm{ml})$ and CNTF $(10 \mathrm{ng} / \mathrm{ml})$. Typically, these cultures are $\sim 95 \%$ OLs, $1-2 \%$ astrocytes, and $1-2 \%$ microglia.

Immunoblot analysis. Lysates were made from cultured OLs or neurons in $1 \%$ SDS and $10 \mathrm{~mm}$ sodium phosphate containing a protease inhibitor cocktail with EDTA (Roche). Protein concentration was measured using the DC Protein Assay (Bio-Rad). Samples $(15 \mu \mathrm{g} /$ lane) were run on an $8 \%$ Tris-HEPES-SDS polyacrylamide gel (Pierce) and electroblotted onto a polyvinylidene fluoride (PVDF) membrane (PerkinElmer Life and Analytical Sciences). PVDF membranes were incubated with an anti-nGLT1 antibody at $1 \mu \mathrm{g} / \mathrm{ml}$ overnight at $4^{\circ} \mathrm{C}$ in TBST buffer (50 mm Tris, $150 \mathrm{~mm} \mathrm{NaCl}$, and $0.01 \%$ Triton, pH 7.4) containing $5 \%$ nonfat milk. Blots were then washed three times in TBST buffer, followed by a $1 \mathrm{~h}$ incubation with HRP-conjugated goat anti-rabbit IgG (GE Healthcare). For protein detection, membranes were incubated in SuperSignal West Pico Chemiluminescence Reagent (Pierce) and exposed on HyBlot CL autoradiography film. Films were scanned using the Wizard Pro Microtek software, and densitometric analysis was performed using NIH ImageJ software. Alternatively, protein detection and densitometric analysis was performed on the Image Reader LAS 3000 (Fujifilm). Densities of glutamate transporter bands were calculated as a percentage of the density in the preOL lysates detected by each antibody. The density of the preOL band was set to $100 \%$. Statistical significance was calculated using two-way ANOVA with Bonferroni's correction. Data are reported with $\mathrm{SD}$ as the measure of dispersion. Ponceau $\mathrm{S}$ staining (Boston Bioproducts) of the blots before transfer was performed to confirm equal loading when comparing preOLs, immature OLs, and mature OL lysates. Immunoblotting of the glyceraldehyde-3phosphate dehydrogenase antibody was also used to confirm equal loading of the lysates.

Immunocytochemistry. Immunocytochemistry was performed on $4 \%$ paraformaldehyde-fixed OLs prepared on coverslips or cryostat cut rat brain sections mounted on slides. Briefly, cells or slides were washed in PBS (in mu: 10 sodium phosphate, 2 potassium phosphate, 2.7 potassium chloride, and 137 sodium chloride, $\mathrm{pH} 7.4$ ) with $0.1 \%$ Triton X-100 (except when using $\mathrm{O} 4$ and $\mathrm{O} 1$ monoclonal antibodies against surface markers that do not require permeabilization) before blocking with $5 \%$ goat serum. Cells or slides were incubated with primary antibodies overnight, followed by washing in PBS. Primary antibody labeling of OLs was detected with immunofluorescent secondary antibodies: Alexa 594 (red) and Oregon 488 (green) (Invitrogen). Sections were mounted with Fluoromount-G (Southern Biotechnology) with added bisbenzamide to identify cell nuclei. Slides were observed using digital or confocal microscopy, and photographs were taken with a Spot digital camera. To ensure reproducibility, staining was replicated three times in OLs from different platings, and in vivo staining was repeated in three different brains at each age.

Imaging. Digital imaging was performed on a Nikon Eclipse E800 equipped with a Spot advanced camera. Confocal imaging was performed on a Zeiss LSM 510 MetA microscope. Pictures were taken using Zeiss LSM software.

Transport studies. Glutamate uptake studies in oligodendrocytes were performed according to previously published procedures (Wang 
et al., 1998) using [ $\left.{ }^{3} \mathrm{H}\right]$ L-glutamate (TRK445) (specific activity, $43 \mathrm{Ci} / \mathrm{mmol}$; GE Healthcare). Briefly, cells were exposed to $\left[{ }^{3} \mathrm{H}\right]_{\mathrm{L}}$ glutamate at a concentration of $20 \mathrm{~nm}$ and 1 $\mu \mathrm{M}$ nonradioactive glutamate, washed with ice-cold choline chloride buffer, and subsequently lysed with $0.1 \mathrm{~mm}$ sodium hydroxide before radioactive uptake was measured by liquid scintillography. The rate of $\left[{ }^{3} \mathrm{H}\right] \mathrm{L}-$ glutamate uptake was found to be linear up to $10 \mathrm{~min}$, so all future experiments were performed for $5 \mathrm{~min}$. To determine the sodiumdependent component of glutamate transport, cells were exposed to $\left[{ }^{3} \mathrm{H}\right] \mathrm{L}$-glutamate and $1 \mu \mathrm{M}$ L-glutamate in the presence or absence of sodium. Uptake of radioactive glutamate that occurred in the absence of sodium was subtracted from that measured in the presence of sodium to determine the sodiumdependent uptake component. Saturation analysis was used to determine $K_{\mathrm{m}}$ and $V_{\max }$ by measuring uptake in the presence of increasing concentrations of L-glutamate with the same concentration of $\left[{ }^{3} \mathrm{H}\right] \mathrm{L}$-glutamate. To determine the contribution of GLT1 in these studies, dihydrokainate (DHK) was used as a specific inhibitor of GLT1 (Pines et al., 1992). TBOA (DL-threo- $\beta$-benzyloxyaspartic acid), a universal inhibitor of all transporters (Bridges et al., 1991, 1999), was compared with inhibition by DHK. Prism GraphPad was used for nonlinear regression analysis as well as Michaelis-Menton transformation of data to determine $K_{\mathrm{m}}$ and $V_{\max }$. All data are representative of three to five replicate experiments.

Approach used to calculate the fractional contribution of each glutamate transporter to glutamate uptake in oligodendrocytes in culture. We calculated the percentage inhibition using concentrations of inhibitor that excluded the effect of the inhibitor on a specific transporter, based on published $K_{\mathrm{i}}$ data (Table 2). For example, the $K_{\mathrm{i}}$ of GLT1 and EAAC1 for the antagonist TBOA is $6 \mu \mathrm{M}$, and the $K_{\mathrm{i}}$ of GLAST for TBOA is $70 \mu \mathrm{M}$ (Shimamoto et al., 1998). The theoretical percentage block of each transporter was calculated at different concentrations of inhibitor with the following equation:

$$
B^{*}=1-\frac{1}{1+\frac{[B]}{K_{\mathrm{i}}\left(1+\frac{[\mathrm{Glu}]}{K_{\mathrm{d}}}\right)}},
$$

where $B^{\star}$ is fraction of the block, $[B]$ is blocker concentration, $K_{\mathrm{i}}$ is dissociation constant of the competitive blocker, [Glu] is glutamate concentration, and $K_{\mathrm{d}}$ is glutamate dissociation constant. The summarized data are presented in Table 3 .

To determine the contribution of GLT1 to glutamate uptake in OLs and neurons, the extent of inhibition by DHK, a specific blocker of GLT1 at $300 \mu \mathrm{M}$ (see Table 2), was determined (see Fig. 5, Table 1).

To determine the contribution of GLAST to glutamate uptake in OLs, the amount of inhibition produced by $30 \mu \mathrm{M}$ TBOA, which should inhibit most of GLT1- and EAAC1-mediated glutamate transport (see Table 3), was subtracted from the amount of inhibition produced by $300 \mu \mathrm{M}$ TBOA, which should inhibit all transporters (see Fig. 5, Table 3).

The following subtraction method describes how the contribution of EAAC1 to glutamate uptake in OLs was determined. Because $30 \mu \mathrm{M}$ TBOA inhibits both GLT1 and EAAC1 (see Table 3), we can approximate the contribution of EAAC1 by subtracting the contribution of GLT1 (Table 1) from the amount of glutamate uptake inhibited by $30 \mu \mathrm{M}$ TBOA (see Fig. 5).
Another way to estimate the contribution of EAAC1 is to measure the inhibition using $1 \mathrm{~mm}$ DHK, which should inhibit $50 \%$ of EAAC1 $\left[K_{\mathrm{i}}\right.$ of $1000 \mu \mathrm{M}$ (Dowd et al., 1996; Davis et al., 1998)], 100\% of GLT1 [ $K_{\mathrm{i}}$ of 8 $\mu \mathrm{M}$ (Wang et al., 1998)], and 0\% of GLAST [ $K_{\mathrm{i}}$ of $>3 \mathrm{~mm}$ (Arriza et al., 1994)]. DHK at $1 \mathrm{~mm}$ inhibits $83 \%$ of glutamate uptake in neurons (see Fig. 5). This value includes the contribution of GLT1, which is $68 \%$ (300 $\mu \mathrm{M}$ DHK) (see Fig. 5), and $50 \%$ of the inhibition observed for EAAC1 (Table 1 ), which is $32 / 2=16 \%$. This value, i.e., $68 \%+16 \%=84 \%$, is very close to the $83 \%$ inhibition observed with $1 \mathrm{~mm}$ DHK, confirming that EAAC1 is responsible for $32 \%$ of the uptake in neurons. Using a similar approach in OLs, we found that $1 \mathrm{~mm}$ DHK inhibited glutamate uptake in preOLs by $48 \%$ (see Fig. 5 ). This value includes the contribution by GLT1, which is $22 \%$ ( $300 \mu \mathrm{M}$ DHK) (see Fig. 5), and $50 \%$ of the inhibition observed for EAAC1 (Table 1 ), or $53 / 2=27 \%$. This value, i.e., $22 \%+27 \%=49 \%$, is very close to the $48 \%$ inhibition observed for $1 \mathrm{~mm}$ DHK, confirming that EAAC1 is responsible for $\sim 50 \%$ of glutamate uptake in preOLs. Similar results were obtained by this approach for the contribution of EAAC1 in mature OLs. A dose-response for DHK in OLs was not performed because very high concentrations of DHK would be needed to inhibit EAAC1 $\left(K_{\mathrm{i}}\right.$ of $\left.1000 \mu \mathrm{M}\right)$ and GLAST $\left(K_{\mathrm{i}}\right.$ of $\left.>3 \mathrm{~mm}\right)$ (Table 2).

Electrophysiology. Electrophysiological experiments were performed in the whole-cell configuration with an Axopatch 200A amplifier and pClamp 8 software (Molecular Devices). Temperature of the chamber (TC-344B; Warner Instruments) containing a $35 \mathrm{~mm}$ Petri dish with cultured preOLs was adjusted to $37^{\circ} \mathrm{C}$. Fast solution exchange was performed with the Fast Step perfusion system SF-77B and computercontrolled valves VC-6 (both from Warner Instruments). Several recordings obtained during subsequent applications of the same set of experimental solutions were averaged to improve signal-to-noise ratio.

For electrophysiological experiments, artificial CSF containing the fol- 


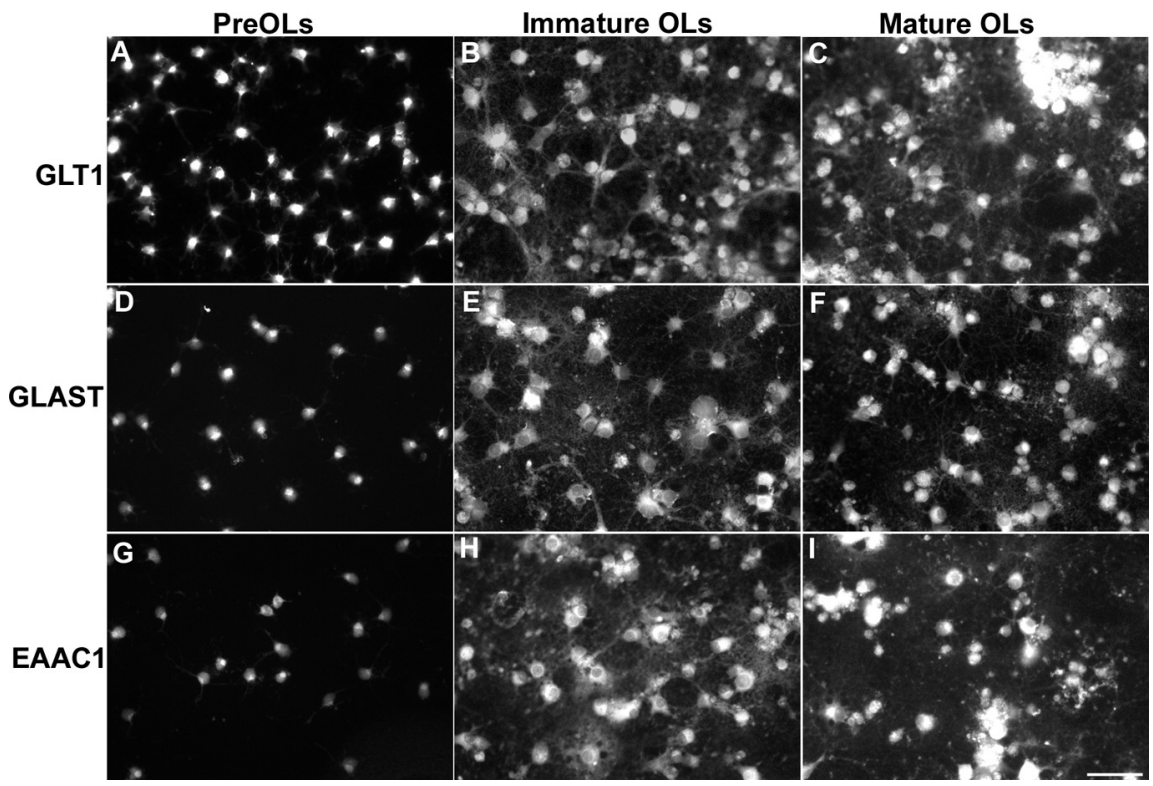

Figure 2. Glutamate transporters GLAST, GLT1, and EAAC1 are expressed in all stages of the cultured rat oligodendrocyte lineage. Immunofluorescent staining using anti-nGLT1 $(\boldsymbol{A}-\boldsymbol{C})$, anti-GLAST (D-F), and anti-EAAC1 antibodies $(\boldsymbol{G}-\boldsymbol{I})$ in pre0Ls $(\boldsymbol{A}$, $\boldsymbol{D}, \boldsymbol{G})$, immature $\mathrm{OLS}(\boldsymbol{B}, \boldsymbol{E}, \boldsymbol{H})$, and mature $0 \mathrm{Ls}(\boldsymbol{C}, \boldsymbol{F}, \boldsymbol{I})$. Scale bar, $50 \mu \mathrm{m}$.

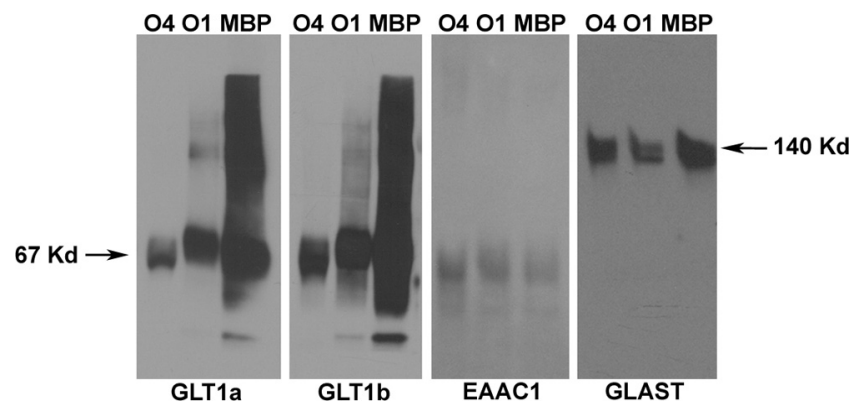

Figure 3. The glutamate transporter GLT1 is significantly increased in cultured rat mature $\mathrm{OLS}$ compared with pre0Ls. Western blot analysis of glutamate transporter expression was performed using total protein lysates made from the oligodendrocyte lineage. Lysates, $15 \mu \mathrm{g} /$ lane, were loaded onto an $8 \%$ Tris-HEPES-SDS acrylamide gel. Western blotting was performed with the glutamate transporter antibodies against EAAC1, GLAST, and the two variant forms of GLT1, GLT1a and GLT1b. GLT1a and GLT1b were highly upregulated in mature OLs. Experiments were repeated three times with lysates cultured from oligodendrocytes at different times.

lowing (in mM) was used: $160 \mathrm{NaCl}, 2.5 \mathrm{KCl}, 2.5 \mathrm{CaCl}_{2}, 1.3 \mathrm{MgCl}_{2}, 10$ D-glucose, and 10 HEPES, pH 7.4, adjusted with $N$-methyl-D-glucamine. The intracellular (pipette) solution contained the following (in $\mathrm{mm}$ ): 1 $\mathrm{NaCl}, 110 \mathrm{KOH}, 20$ tetraethylammonium, $1 \mathrm{CaCl}_{2}, 5 \mathrm{MgCl}_{2}, 5 \mathrm{EGTA}$, and 10 HEPES, pH 7.2, adjusted with gluconic acid. Osmolarity in all solutions was adjusted to $330 \mathrm{mOsm}$ with mannitol. With these solutions, $E_{\mathrm{Cl}}=-70 \mathrm{mV}$. In this case, the glutamate-activated chloride current associated with glutamate transporter anionic conductivity did not contribute to the total membrane current at the holding potential of -70 $\mathrm{mV}$. To block any ionotropic glutamate receptor currents and other nontransporter currents, we used similar drugs to those used to detect glutamate transporter currents in astrocytes (Bergles and Jahr, 1998), specifically the following: $10 \mu \mathrm{M}(R S)-3$-(2-carboxypiperazin-4-yl)propyl-1-phosphonic acid, $100 \mu \mathrm{M}$ 5,7-dichlorokynurenic acid, $10 \mu \mathrm{M}$ 2,3-dioxo-6-nitro-1,2,3,4-tetrahydrobenzoquinoxaline-7-sulfonamide (NBQX), $50 \mu \mathrm{M}$ 4-(8-methyl-9H-1,3-dioxolo[4,5-h][2,3]benzodiazepin-5-yl)-benzenamine (GYKI 52466), as well as $0.3 \mu \mathrm{M}$ TTX and $25 \mu \mathrm{M}$ bicuculline. Experimental data are presented as mean \pm SEM. Twotailed or one-tailed $t$ tests were used when appropriate to determine significance of the differences.

\section{Results}

Expression of glutamate transporters in cultured OLs

Previously, we showed that GLT1 expression in the human cerebral white matter is primarily limited to developing OLs before birth and is rarely observed in astrocytes until after term birth (DeSilva et al., 2007). Furthermore, vesicular release of glutamate from growing axons has been shown to stimulate AMPA receptors on $\mathrm{NG}^{+}$glial precursors in rat cerebral white matter (Ziskin et al., 2007). Therefore, we surmised that developing OLs play a major role in maintaining glutamate homeostasis in the cerebral white matter. To further understand the role of glutamate transporters in OLs, we characterized the expression and function of glutamate transporters in cultured rat OLs at different stages of development. Primary rat OLs were cultured according to methods established in our laboratory (Rosenberg et al., 2003) producing three different stage specific cultures: preOLs $\left(\mathrm{O}^{+}, \mathrm{O}^{-}, \mathrm{MBP}^{-}\right)$; immature OLs $\left(\mathrm{O}_{4}^{+}, \mathrm{O}^{+}, \mathrm{MBP}^{-}\right)$; and mature OLs $\left(\mathrm{O}^{+}\right.$, $\left.\mathrm{O}^{+}, \mathrm{MBP}^{+}\right)$. Immunocytochemistry was performed to evaluate the expression of $\mathrm{A} 2 \mathrm{~B} 5, \mathrm{O} 4, \mathrm{O} 1$, and $\mathrm{MBP}$ immunoreactivity at each stage of the rat OL lineage (Fig. 1). In the preOL stage, all OLs stained with the A2B5 (Fig. 1A) and O4 (B) antibodies, and almost no staining was seen with the $\mathrm{O} 1(C)$ and anti-MBP $(D)$ antibodies. In the immature stage, a marked decrease in A2B5 staining was observed $(E)$, and all OLs stained with $\mathrm{O} 4(F)$ and $\mathrm{O} 1(G)$ antibodies but relatively few with the anti-MBP antibody $(H)$. In the mature stage, very little expression of A2B5 immunoreactivity was observed (I), and all OLs stained with the $\mathrm{O} 4(\mathrm{~J}), \mathrm{O} 1(K)$, and anti-MBP $(L)$ antibodies. These results were similar to those observed previously (Back et al., 1998; Deng et al., 2003).

Immunocytochemistry using specific antibodies against GLT1 (Fig. $2 A-C$ ), GLAST ( $D-F$ ), and EAAC1 ( $G-I$ ) showed the expression of all three transporters in cultured rat preOLs $(A, D, G)$, immature OLs $(B, E, H)$, and mature OLs $(C, F, I)$. Immunoblot analysis of lysates made from cultured rat preOLs, immature OLs, and mature OLs showed that GLT1a, GLT1b, EAAC1, and GLAST were present at all stages of development (Fig. 3). However, GLT1a and GLT1b were upregulated $1000 \pm 100$ and $800 \pm 100 \%$, respectively, in MBP OLs compared with $\mathrm{O} 4 \mathrm{OLs}$, as demonstrated using densitometric analysis $(p<0.001)$. In O1 OLs compared with O4 OLs, GLT $1 \mathrm{a}$ and GLT $1 \mathrm{~b}$ were upregulated $500 \pm 40$ and $400 \pm 40 \%$ $(p<0.001)$. The density for EAAC1 and GLAST in O1 OLs compared with O4 OLs was $100 \pm 10$ and $90 \pm 10 \%$, respectively, and these differences were not statistically significant $(p>0.05)$. The density for EAAC1 and GLAST in MBP OLs compared with O4 OLs was $80 \pm 10$ and $130 \pm 12 \%$, respectively, and these differences were also not statistically significant $(p>0.05)$. These data demonstrate that only the GLT1 glutamate transporter is developmentally regulated in the OL lineage in culture. 
Oligodendrocytes throughout their lineage in culture are capable of highaffinity sodium-dependent glutamate uptake

Glutamate uptake in cultured rat OLs at different stages of development was characterized to determine whether the increase in GLT1 protein expression at the MBP stage observed by Western blot was associated with an increase in function. Glutamate transporters are sodium dependent. Assay of sodium-dependent glutamate uptake was performed as described previously (Wang et al., 1998), measuring $\left[{ }^{3} \mathrm{H}\right] \mathrm{L}$-glutamate uptake in the presence and absence of sodium using choline as the substitute for sodium. Uptake of radioactive glutamate that occurred in the absence of sodium was subtracted from that measured in the presence of sodium to determine the sodium-dependent uptake component, which was $95 \%$ of the total uptake (Fig. 4). Uptake into preOLs, immature OLs, and mature OLs was found to be linear up to $10 \mathrm{~min}$ (data not shown). In all subsequent experiments, therefore, uptake was measured over a $5 \mathrm{~min}$ interval.

To determine the glutamate uptake capacity of cultured rat OLs, saturation analysis of glutamate uptake was performed in preOLs, immature OLs, and mature OLs (Fig. 4A). Uptake of [ $\left.{ }^{3} \mathrm{H}\right] \mathrm{L}$-glutamate into OLs was measured at increasing concentrations of L-glutamate up to $1 \mathrm{~mm}$, and saturation was observed at $\sim 300 \mu \mathrm{M}$. Nonlinear regression analysis demonstrated that $\left[{ }^{3} \mathrm{H}\right] \mathrm{L}$-glutamate uptake data were best fit using a one-site MichaelisMenten model. The $K_{\mathrm{m}}$ values for all stages of development were $10 \pm 2 \mu \mathrm{M}$, with a $V_{\max }$ of $3.0 \pm 1.0,5.0 \pm 1.0$, and $4.0 \pm 1.0$ $\mathrm{nmol} \cdot \mathrm{min}^{-1} \cdot \mathrm{mg}^{-1}$ for preOLs, immature OLs, and mature OLs, respectively. These data demonstrate that the large increase in GLT1 protein expression at the MBP stage does not correlate with a significant increase in glutamate uptake.

To confirm that our data reflect glutamate uptake specifically by glutamate transporters, we used both competitive and noncompetitive inhibitors of glutamate transport. Experiments were performed in the presence of $300 \mu \mathrm{M}$ TBOA, a competitive, nontransportable blocker of all glutamate transporters as well as 300 $\mu \mathrm{M}$ PDC (L-trans-pyrrolidine-2,4-dicarboxylic acid), a competitive transportable blocker of glutamate transporters (Fig. 4A). Increasing concentrations of glutamate diminished the effectiveness of the antagonists TBOA and PDC, confirming that glutamate transporters account for the measured glutamate uptake.

\section{Cellular localization of GLT1 in developing and mature oligodendrocytes}

Immunoblotting of total protein lysates from cultured OLs demonstrated that GLT1 is significantly increased in mature OLs compared with preOLs. However, a concomitant increase in
PreOLs
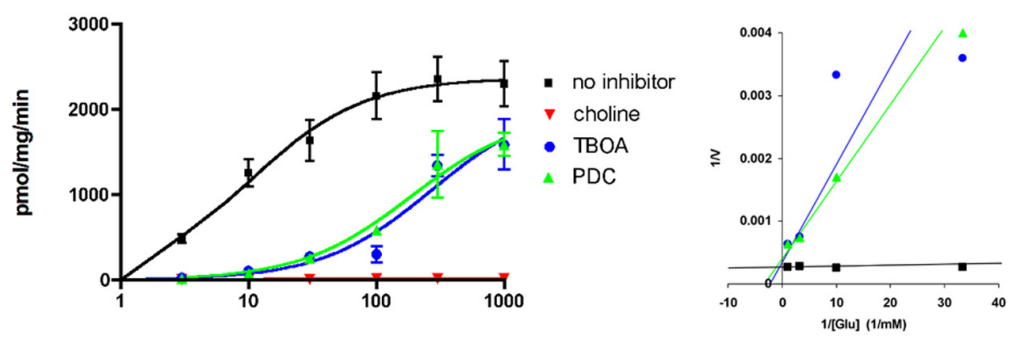

MBP OLs

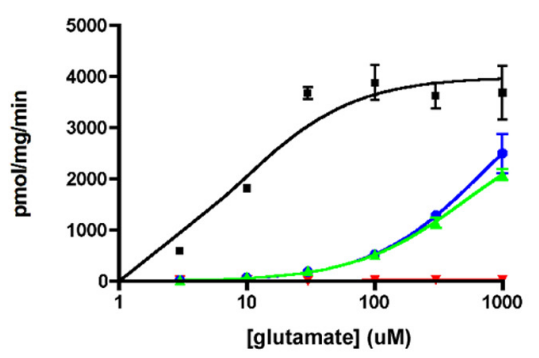

- no inhibitor

$\checkmark$ choline

- TBOA

$\triangle \mathrm{PDC}$
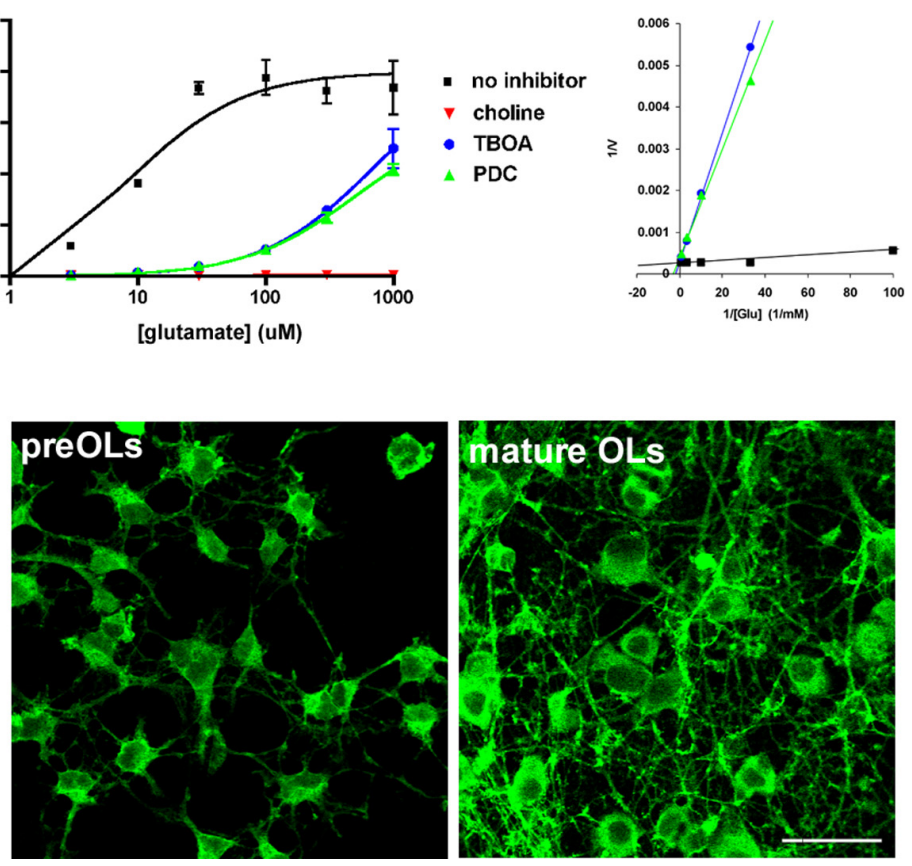

Figure 4. OLs in culture have similar glutamate transport capacity across their lineage. $A$, Glutamate transport in $0 \mathrm{Ls}$ was measured using $\left[{ }^{3} \mathrm{H}\right] \mathrm{L}$-glutamate uptake. In the absence of sodium (choline substituted for sodium), glutamate transport into pre0Ls was reduced to $10 \%$. Data were fit to a curve by nonlinear regression analysis using a one-site model. The $K_{\mathrm{m}}$ value s (data not shown), and mature $0 \mathrm{Ls}$, respectively. Glutamate transport was reduced to $5 \%$ in the presence of the universa mate transporter blockers TBOA, a competitive nontransportable blocker of sodium-dependent glutamate transporters, as microscopy demonstrated increased expression of GLT1 in cultured mature $0 \mathrm{~L}$ processes compared with pre $0 \mathrm{Ls}$. Cultured pre $0 \mathrm{Ls}$ and mature $0 \mathrm{Ls}$ immunofluorescently stained with an anti-GLT1a antibody were observed by confocal imaging at $63 \times$ magnification. Increased expression of GLT1 was observed in processes of mature OLs. Scale bar, $50 \mu \mathrm{m}$.

$\left[{ }^{3} \mathrm{H}\right] \mathrm{L}$-glutamate uptake at the mature OL stage was not observed. To further investigate the discrepancy between increased protein expression of GLT1 in MBP OLs compared with preOLs and the absence of a significant increase in glutamate uptake in MBP OLs, confocal imaging studies were performed to explore whether there was a change or redistribution of GLT1 expression during development. Confocal imaging studies showed that the increase in the expression of GLT1 in mature OLs was primarily in the extensive processes, which are not present in preOLs (Fig. 4B).

Contribution of specific glutamate transporters to glutamate uptake across the oligodendrocyte lineage

To determine the relative contribution of each transporter (GLT1, EAAC1, and GLAST) to glutamate uptake in cultured rat OLs, the differential effect of transport blockers on glutamate uptake in OLs was measured. For comparison, we performed the 


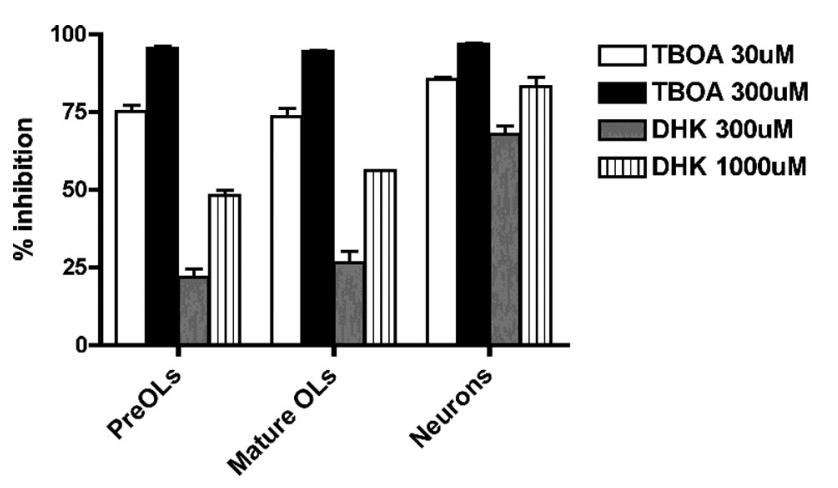

\begin{tabular}{|l|l|l|l|c|}
\hline $\begin{array}{c}\text { Oligodendrocyte } \\
\text { stage }\end{array}$ & $\begin{array}{c}\text { 30uM } \\
\text { TBOA }\end{array}$ & $\begin{array}{l}\mathbf{3 0 0 u M} \\
\text { TBOA }\end{array}$ & $\begin{array}{c}\mathbf{3 0 0 u M} \\
\text { DHK }\end{array}$ & $\begin{array}{c}\text { 1000uM } \\
\text { DHK }\end{array}$ \\
\hline PreOLs & $75 \pm 2 \%$ & $95 \pm 0.5 \%$ & $22 \pm 2 \%$ & $48 \pm 2 \%$ \\
\hline Mature OLs & $74 \pm 3 \%$ & $94 \pm 0.5 \%$ & $27 \pm 3 \%$ & $56 \pm 1 \%$ \\
\hline Neurons & $85 \pm 1 \%$ & $95 \pm 0.5 \%$ & $68 \pm 3 \%$ & $83 \pm 3 \%$ \\
\hline
\end{tabular}

Figure 5. Dissection of contribution of specific glutamate transporters to glutamate transport. To determine the contribution of GLT1 in these studies, DHK was used as a specific inhibitor of GLT1 at $300 \mu \mathrm{m}$. At $1000 \mu \mathrm{m}$ DHK, GLT1 and 50\% of glutamate uptake by EAAC1 are inhibited (Table 2). Inhibition by TBOA, a universal inhibitor of all glutamate transporters, was compared with inhibition by DHK. At $300 \mu \mathrm{M}$ TBOA, EAAC1 and GLT1 are inhibited, but not GLAST (see Table 2).

same type of experiment on cultured rat cerebral neurons, which only express GLT1 and EAAC1 (Wang et al., 1998). TBOA, a universal inhibitor of all transporters (Bridges et al., 1991), was found to have an $\mathrm{IC}_{50}$ value of $11 \pm 1,13 \pm 1$, and $10 \pm 1 \mu \mathrm{M}$ for preOLs, mature OLs, and neurons, respectively (supplemental Fig. 1, available at www.jneurosci.org as supplemental material), and $K_{\mathrm{i}}$ values of $10 \mu \mathrm{M}$ for preOLs and $12 \mu \mathrm{M}$ for mature OLs. $K_{\mathrm{m}}$ values for glutamate used to calculate these $K_{\mathrm{i}}$ values were derived from the data shown in Figure 4 . The $K_{\mathrm{i}}$ value for neurons was 9 $\mu \mathrm{M}$ using the previously published $K_{\mathrm{m}}$ value for glutamate of 17.2 $\mu \mathrm{M}$ (Wang et al., 1998). TBOA, a universal inhibitor of glutamate transporters, at $300 \mu \mathrm{M}$ inhibited glutamate transport in preOLs, mature OLs, and neurons $95 \pm 0.5,94 \pm 0.5$, and $95 \pm 0.3 \%$, respectively (Fig. 5). In contrast, DHK, a specific blocker of GLT1 at $300 \mu \mathrm{M}$ (Table 3), inhibited glutamate uptake $22 \pm 2.5 \%$ in preOLs and $27 \pm 3.5 \%$ in mature OLs (Fig. 5). Previously, we showed that there was no change in total glutamate uptake in mature OLs compared with preOLs (Fig. 4), which was unexpected based on Western blot data (Fig. 3). Similarly, the proportion of glutamate uptake contributed by GLT1 determined here (Fig. 5) was not increased.

The contribution of GLT1 to total glutamate uptake in neurons is $\sim 68 \%$ (Fig. 5), with EAAC1 responsible for the remainder because GLAST is not expressed in these cells (Table 1). OLs, however, express GLAST, in addition to EAAC1 and GLT1. Unfortunately, there is not a specific blocker to differentiate the contribution of EAAC1. This problem was circumvented by comparing the effects of DHK and TBOA at different concentrations (see Materials and Methods). EAAC1 was responsible for $\sim 53$ and $48 \%$ of the uptake in preOLs and mature OLs, respectively (Table 1). To estimate the fraction of glutamate uptake in OLs attributable to GLAST the amount of inhibition produced by $30 \mu \mathrm{M}$ TBOA, which should inhibit most of GLT1- and EAAC1mediated glutamate transport (Table 3), was subtracted from the amount of inhibition produced by $300 \mu \mathrm{M}$ TBOA, which should inhibit all transporters (Fig. 5, Table 3). Cultured neurons do not express GLAST, and, as expected, the difference in inhibition between $30 \mu \mathrm{M}$ TBOA and $300 \mu \mathrm{M}$ TBOA was not significant (Fig. 5). In contrast, preOLs and mature OLs do express GLAST, and the difference in inhibition between $30 \mu \mathrm{M}$ TBOA and $300 \mu \mathrm{M}$ TBOA was significant $(p<0.001)$ (Fig. 5). The contribution of GLAST in preOLs and mature OLs was $\sim 25 \%$ (Table 1 ).

\section{Electrophysiological recordings of glutamate transporter currents in oligodendrocytes}

Glutamate transporters are not primary active transporters, which use energy directly derived from ATP hydrolysis, but are rather secondary active transporters, which derive the energy to perform the work of concentrating glutamate by coupling the transport of glutamate with the transport of ions diffusing down their concentration gradients. For each cycle of the transporter, 1 glutamate ${ }^{-}, 3 \mathrm{Na}^{+}$, and $1 \mathrm{H}^{+}$are transported into the cell, and 1 $\mathrm{K}^{+}$is transported out of the cell. This stoichiometry makes glutamate transport electrogenic and allows for electrophysiological measurement of glutamate transport current to assay glutamate transporter function. Whole-cell patch-clamp electrophysiological recordings were performed in cultured rat preOLs to complement $\left[{ }^{3} \mathrm{H}\right] \mathrm{L}$-glutamate uptake studies to confirm the function of glutamate transporters in preOLs. Application of $30 \mu \mathrm{M}$ glutamate produced an inward transporter current $(0.7 \pm 0.5 \mathrm{pA} / \mathrm{pF}$, $n=4)$ in OLs with $17 \pm 4 \mathrm{pF}(n=4)$ in the presence of blockers of glutamate receptors (Fig. 6). TBOA (50 $\mu \mathrm{M})$ and DHK (300 $\mu \mathrm{M})$ inhibited this glutamate-activated current, showing it to be mediated by glutamate transporters (Fig. 6). Higher concentrations of glutamate $(30 \mu \mathrm{M})$ were used in electrophysiological experiments than in radioactive uptake experiments to yield a higher signal-to-noise ratio. TBOA did not completely block the transporter currents because of the competitive nature of the inhibition, as well as the fact that $50 \mu \mathrm{M}$ TBOA is below the $K_{\mathrm{i}}$ value for GLAST (Table 2).

\section{Cellular expression of GLT1 in the rat corpus callosum throughout development}

Immunoblotting of total protein lysates from rat cultured OLs demonstrated that GLT1 is significantly increased in mature $\mathrm{MBP}^{+}$OLs in culture (Fig. 3). Previously, we showed that GLT1 is highly expressed in developing OLs but not in mature $\mathrm{MBP}^{+}$ OLs in the human cerebral white matter (DeSilva et al., 2007). To further explore the potential species discrepancy between the in vitro expression of GLT1 in cultured mature $\mathrm{MBP}^{+}$rat OLs and its lack of expression in vivo in $\mathrm{MBP}^{+} \mathrm{OLs}$ in the human cerebral white matter, immunocytochemical studies in the developing rat corpus callosum were undertaken. In P1 rat corpus callosum, there were numerous $\mathrm{A} 2 \mathrm{~B} 5{ }^{+}$and $\mathrm{O} 4{ }^{+} \mathrm{OLs}$ (supplemental Fig. 2, available at www.jneurosci.org as supplemental material); these cells expressed GLT1 (Fig. 7A-F). At this age, however, there was no expression of mature $\mathrm{MBP}^{+} \mathrm{OLs}$, cells that form the myelin ensheathment of axons (supplemental Fig. 3, available at www. jneurosci.org as supplemental material). However, there were plentiful unmyelinated axons in the corpus callosum as evidenced by staining using the neurofilament marker SMI 312 (supplemental Fig. 3, available at www.jneurosci.org as supplemental material). In the $\mathrm{P} 3$ compared with $\mathrm{P} 1$ rat brain, there was similar labeling using the A2B5 antibody but increased labeling with the antibodies $\mathrm{O} 4$ and $\mathrm{O} 1$ (supplemental Fig. 2, available at www.jneurosci.org as supplemental material). Again, at this age, there was no labeling with an antibody against MBP, but strong staining of unmyelinated axons by SMI 312 was observed (supplemental Fig. 3, available at www.jneurosci.org as supplemental 
material). GLT1 was not expressed in these unmyelinated axons, but there were clusters of GLT1-positive cells surrounding these axons (Fig. $8 A-C$ ). In the P7 and $\mathrm{P} 20$ rat brain, there was a downregulation in expression of $\mathrm{A} 2 \mathrm{~B} 5$, but $\mathrm{O} 4$ and

O1 staining persisted (supplemental Fig. 2, available at www. jneurosci.org as supplemental material). In the $\mathrm{P} 7$ rat brain, there was some expression of MBP (supplemental Fig. 3, available at www.jneurosci.org as supplemental material) that did not colocalize with GLT1 (Fig. 8D-F). There was extensive MBP staining in the P20 (supplemental Fig. 3, available at www.jneurosci.org as supplemental material), P30, and P60 (data not shown) rat brain that did not colocalize with GLT1 staining (data not shown). Premyelinating cells at $\mathrm{P} 20$ remain positive for GLT1 (Fig. 7), and a comparison of GLT1 expression in $\mathrm{O} 1{ }^{+} \mathrm{OLs}$ (Fig. 7G-I) in the P7 corpus callosum to GLT1 expression in $\mathrm{O} 1^{+}$ OLs (Fig. 7J-L) in the P20 corpus callosum is shown.

\section{Discussion}

We present data on the expression of glutamate transporters in the OL lineage during development. In vivo, GLT1 is expressed in preOLs and immature OLs but not in mature $\mathrm{MBP}^{+}$OLs in the developing human (DeSilva et al., 2007) and rat brain (data shown here). In contrast, immunoblotting of lysates from cultured rat OLs demonstrated that GLT1 is present at all stages of OL development; moreover, GLT1 was significantly increased in cultured rat mature OLs compared with preOLs, contrary to the in vivo observations. Using DHK, a specific GLT1 blocker, we found that GLT1 was responsible for $\sim 25 \%$ of glutamate uptake in all stages of OL development. $\left[{ }^{3} \mathrm{H}\right] \mathrm{L}$-glutamate uptake studies did not show a concomitant increase in uptake in mature OLs corresponding to the increase in protein expression. These findings suggest that GLT1 expression in OLs is highly regulated during normal development, and it will be important subsequently to determine the factors responsible for this regulation in vivo that appear to be absent in vitro.

\section{EAAC1 is a major glutamate transporter in OLs}

Our data show that EAAC1 is responsible for $\sim 50 \%$ of glutamate uptake in cultured rat OLs, with GLT1 and GLAST contributing $25 \%$, respectively. Surprisingly, our results show that EAAC1 is a major contributor to glutamate uptake in OLs, although it is considered to be the neuronal glutamate transporter (Danbolt, 2001). Studies in rat optic nerve and human spinal cord OL cultures showed expression of EAAC1, GLAST, and GLT1, but GLT1 was reported to be the major contributor to glutamate uptake (Domercq et al., 1999; Pitt et al., 2003). However, these studies used $1 \mathrm{~mm}$ DHK to inhibit glutamate transport, which at this concentration is not specific for GLT1 [ $K_{\mathrm{i}}$ value for EAAC1 of $1 \mathrm{~mm}$ (Dowd et al., 1996)]. DHK at $1 \mathrm{~mm}$ would be expected to inhibit $50 \%$ of glutamate transport contributed by EAAC1, whereas DHK at $300 \mu \mathrm{M}$ inhibits 99\% GLT1-mediated and $20 \%$ of EAAC1-mediated transport (Table 3). Electrophysiological recordings from GLAST and GLT1 bacterial artificial chromosome transgene mice at P24 showed that GLT1 plays a greater role in glutamate uptake in spinal cord OLs than corpus callosum OLs (Regan et al., 2007); EAAC1 expression and function were not explored.

Why oligodendrocytes would necessitate the function of three glutamate transporters needs additional investigation. EAAC1 is considered to be the neuronal glutamate transporter, although the role of neuronal glutamate uptake by EAAC1 is somewhat
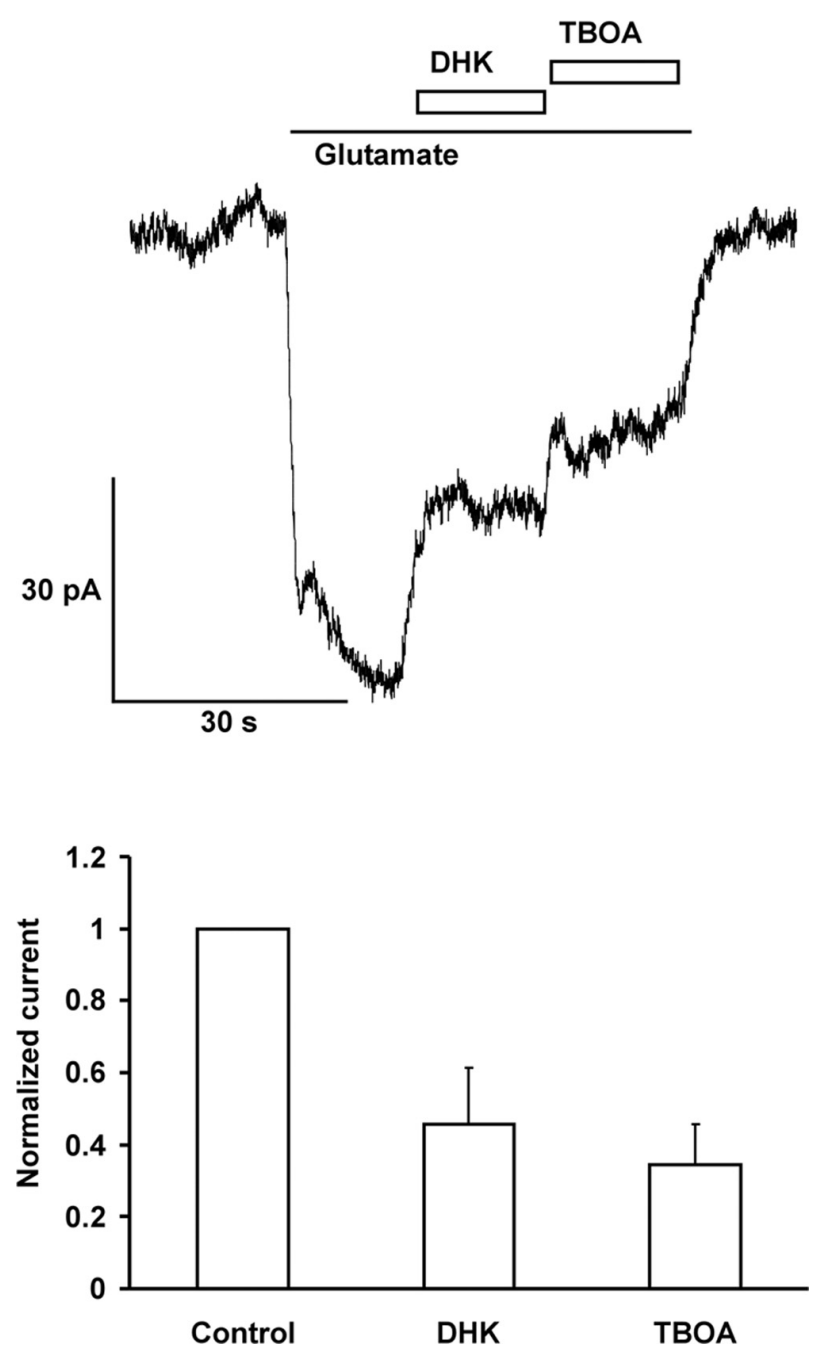

Figure 6. Glutamate transporter-mediated currents are present in cultured rat OLs. The effect of blockers of glutamate transport on the glutamate-evoked whole-cell coupled transporter current in cultured pre0Ls was determined in the presence of $10 \mu \mathrm{M} \mathrm{NBQX}$ and $50 \mu \mathrm{m}$ GYKI 52466 to block glutamate receptor-mediated currents. Glutamate simulated an inward current $(0.7 \pm 0.5 \mathrm{pA} / \mathrm{pF}, n=4)$ that was blocked by DHK, a specific inhibitor of GLT1, and by TBOA, a universal blocker of glutamate transporters ( $p<0.05$ and $p<0.005$, respectively; mean $\pm \mathrm{SEM} ; n=4$ ). All currents in each cell were normalized to glutamate-evoked current.

ambiguous (Coco et al., 1997; Conti et al., 1998). GLT1, thought to be exclusively an astrocytic transporter, is also found on presynaptic terminals (Chen et al., 2004; Furness et al., 2008). A possible likely function of EAAC1 in neurons may be to transport L-cysteine (Zerangue and Kavanaugh, 1996). Cysteine is a precursor of glutathione, which is a major antioxidant in cells. Glutathione deficiency has been shown to be associated with oxidative stress and neurodegenerative disorders (Jain et al., 1991; Schulz et al., 2000). In fact, EAAC1-null mice were found to have reduced glutathione levels, increased oxidant levels, and increased susceptibility to oxidant injury, which was reversed by treatment with $N$-acetylcysteine, a cysteine precursor (Aoyama et al., 2006). Developing oligodendrocytes have also been shown to be vul- 


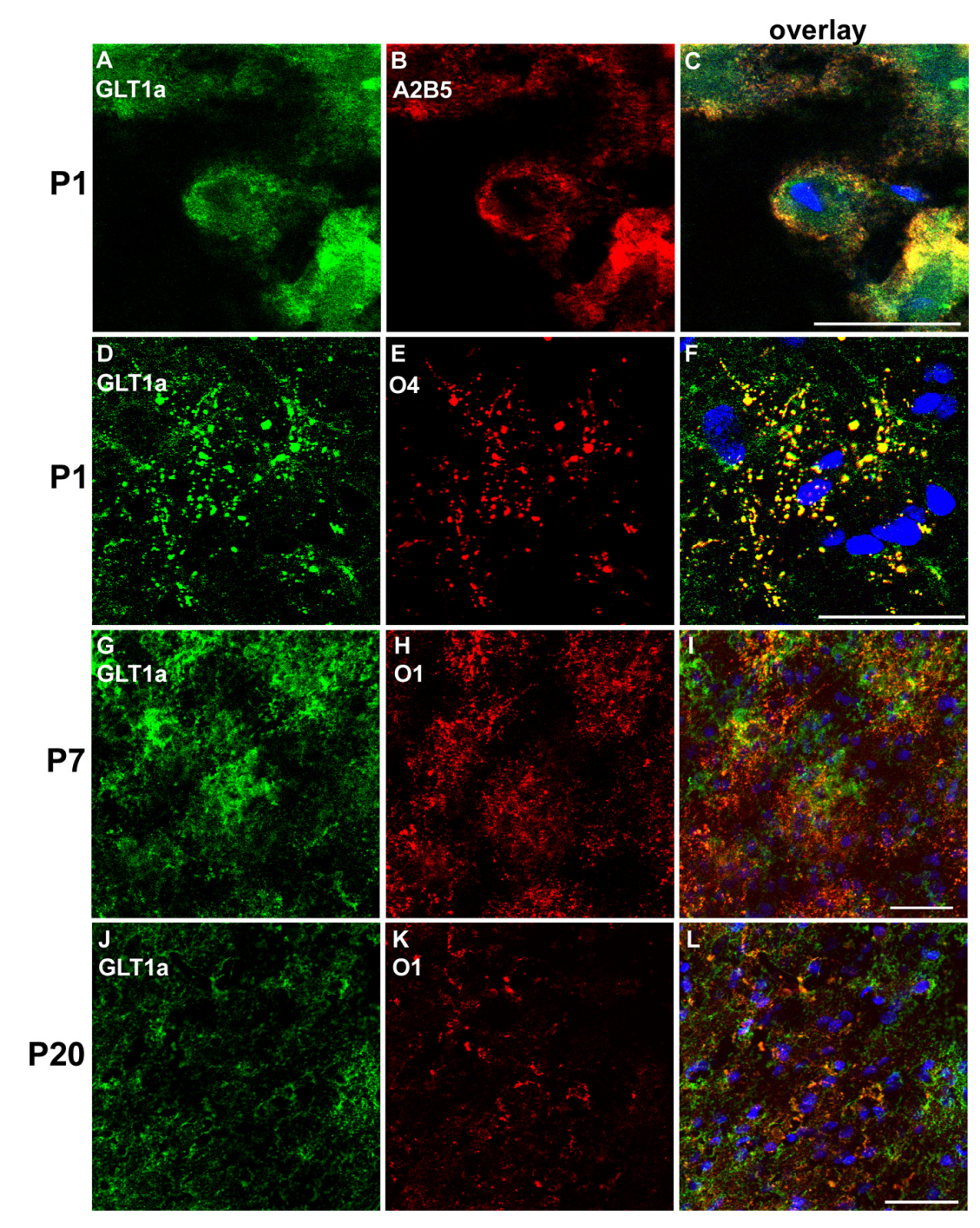

Figure 7. GLT1 is expressed in developing $0 \mathrm{Ls}$ from rat corpus callosum. Double-labeled immunocytochemistry of P1 rat corpus callosum using an anti-GLT1a antibody $(\boldsymbol{A}, \boldsymbol{D})$, and monoclonal antibodies A2B5 $(\boldsymbol{B})$ and $04(\boldsymbol{E})$ was observed using confocal microscopy $(60 \times)$. Colocalization of GLT1 with A2B5 $(\boldsymbol{C})$ and $04(\boldsymbol{F})$ immunoreactivity was found. Expression of GLT1 in developing oligodendrocytes persisted after myelination in the developing corpus callosum. Double-labeled immunocytochemistry in the P7 rat corpus callosum using an anti-GLT1a antibody $(\boldsymbol{G})$ and the 01 monoclonal antibody $(\boldsymbol{H})$ observed with confocal microscopy $(20 \times)$. Overlay of $\boldsymbol{G}$ and $\boldsymbol{H}$ demonstrated $\mathrm{GLT} 1$ in 01 -positive $0 \mathrm{Ls}(\boldsymbol{I})$. Double-labeled immunocytochemistry in the P20 rat corpus callosum using an anti-GLT1a antibody $(\boldsymbol{J})$ and the 01 monoclonal antibody $(\boldsymbol{K})$ was observed with confocal microscopy $(20 \times)$. Overlay of $\boldsymbol{J}$ and $\boldsymbol{K}$ demonstrated GLT1 in 01-positive $0 \mathrm{Ls}(\boldsymbol{L})$. Bisbenzamide was used to stain cell nuclei blue. Scale bar, $50 \mu \mathrm{m}$.

nerable to oxidative stress induced by glutathione depletion, resulting in cell death (Oka et al., 1993; Back et al., 1998; Baud et al., 2004; Wang et al., 2004). The fact that EAAC1 is a cysteine transporter suggests that an important role of EAAC1 in oligodendrocytes may also be to provide cysteine as a precursor for glutathione synthesis.

\section{Expression of GLT1 across the oligodendrocyte lineage in vivo and in vitro}

In this study, we showed that GLT1 is expressed in developing rat cerebral white matter in cells expressing the markers for A2B5 ${ }^{+}$, $\mathrm{O}_{4}{ }^{+}$, and $\mathrm{O} 1{ }^{+} \mathrm{OLs}$. At P7, there is some expression of MBP that does not colocalize with GLT1, and, at older ages (P20), when $\mathrm{MBP}^{+}$expression is abundant, GLT1 is also not expressed in $\mathrm{MBP}^{+}$OLs. Conversely, immunoblot analysis of GLT1 expression in cultured OLs showed an upregulation of GLT1 in mature compared with preOLs and immature OLs. Together, these data suggest that the downregulation of GLT1 in mature OLs observed in vivo in the rat brain may be the consequence of a signaling process that is not present in the culture system.

Many lines of evidence suggest that glutamate may be an important signaling factor for oligodendrocyte differentiation and proliferation in the developing cerebral white matter. The glutamate receptor agonists kainate or AMPA have been shown to decrease the number of OLs expressing $\mathrm{NG}_{2}{ }^{+}$and $\mathrm{O}_{4}^{+}$markers and their proliferation (indicated by bromodeoxyuridine labeling) in cerebellar organotypic slices (Yuan et al., 1998). Consistent with these observations, the glutamate receptor antagonist DNQX increased the percentage of $\mathrm{NG}_{2}{ }^{+}$and $\mathrm{O}_{4}^{+} \mathrm{OLs}$ and their proliferation (Yuan et al., 1998). AMPA has also been shown to stimulate migration of OL precursors positive for the PDGF receptor in rat mixed glia cultures (Gudz et al., 2006). These data strongly implicate glutamate as an important signaling molecule for developing OLs.

Confocal imaging showed that GLT1 was highly expressed in the extensive processes of $\mathrm{MBP}^{+} \mathrm{OLs}$ that are not present in preOLs. This expression in processes of GLT1 is likely to account for the increased expression of GLT1 seen in Western blot analysis. The observation that there was not an increase in uptake commensurate with the observed increase in expression of GLT1 suggests that GLT1 expressed in the processes was not functional or was underrepresented in the procedures we have used to measure glutamate uptake. Because the volume to surface ratio in the processes is much smaller than in the cell body, glutamate transport will cause relatively fast accumulation of glutamate and sodium in the processes. This will reduce the driving force for glutamate transport, resulting in diminished glutamate uptake in the processes compared with the cell body during the duration of the experiment.

During cerebral white matter development, oligodendrocytes may play an important role in maintaining glutamate homeostasis

Previously, we showed that EAAT2 (the human homolog of GLT1) expression is primarily limited to premyelinating OLs early in human development and is rarely observed in astrocytes until $>40$ weeks after conception (DeSilva et al., 2007, 2008). No astrocytic expression of EAAT2 protein was found in the developing human CNS (Furuta et al., 2005) or in human cultured glial progenitors (Maragakis et al., 2004). Astrocytic expression of GLT1 also was not observed in rat cerebral white matter (Furuta et al., 1997), mouse spinal cord (Yamada et al., 1998), and sheep corpus callosum (Northington et al., 1999) until postnatal development. In the adult mammalian brain, it has been assumed that 
glutamate uptake by GLT1 in astrocytes has the major role in maintaining glutamate homeostasis (Rosenberg and Aizenman, 1989; Rosenberg et al., 1992; Tanaka et al., 1997; Bergles et al., 1999; Danbolt, 2001). The observation that GLT1 is not expressed in astrocytes during cerebral white matter development suggests that the expression of glutamate transporters in developing OLs, including GLT1, GLAST, and EAAC1, may play an important role in maintaining glutamate homeostasis. Vesicular release of glutamate from unmyelinated axons has been shown to induce AMPA receptor-mediated currents in glial progenitors $\left(\mathrm{NG}^{+}{ }^{+}\right.$) (Ziskin et al., 2007), cells identified in the current experiments by labeling with the A2B5 ${ }^{+}$ monoclonal antibody and that we have shown to be positive for GLT1 in this study. $\mathrm{NG}^{+}$cells are immunopositive for $\mathrm{A} 2 \mathrm{~B} 5$, and, with maturation, there is a gradual progression from $\mathrm{NG}^{+} / \mathrm{O}^{-}$to $\mathrm{NG} 2{ }^{+} / \mathrm{O} 4{ }^{+}$OLs, followed by loss of NG2 antigenicity during additional OL differentiation (Levine et al., 1993; Dawson et al., 2003; Polito and Reynolds, 2005). Our present data regarding expression of glutamate transporters and our previously published data (DeSilva et al., 2007, 2008) in addition to electrophysiological studies (Ziskin et al., 2007) suggest that cells in the OL lineage are targets for glutamatergic signaling by unmyelinated axons. Glutamate signaling requires a mechanism for the regulation of extracellular glutamate concentration, emphasizing the importance of glutamate transporters.

\section{The role of GLT1 in excitotoxicity and} periventricular leukomalacia

Glutamate transporters couple the transport of glutamate with sodium and potassium. Therefore, glutamate transporters are likely to reverse transport and release glutamate during hypoxiaischemia as a result of the disruption in membrane ion gradients. We speculate that cerebral white matter is particularly vulnerable to ischemic injury because of the coincident expression of glutamate receptors and glutamate transporters on OLs. It is noteworthy that the excitotoxic component of cell injury during oxygenglucose deprivation in developing OLs can be blocked by an inhibitor of GLT1 with the same degree of protection as conferred by blockade of glutamate receptors (Fern and Möller, 2000; Deng et al., 2003), suggesting a disproportionately large contribution of GLT1 to reverse transport in these cells. The question arises why would the expression of GLT1 per se be important in producing vulnerability to hypoxia-ischemia, because the data presented in this study show that GLT1 is responsible for only $25 \%$ of glutamate uptake in preOLs. Together, these data suggest that there may be a unique structural attribute of GLT1 that favors its propensity to reverse transport compared with GLAST and EAAC1.

\section{References}

Aoyama K, Suh SW, Hamby AM, Liu J, Chan WY, Chen Y, Swanson RA (2006) Neuronal glutathione deficiency and age-dependent neurodegeneration in the EAAC1 deficient mouse. Nat Neurosci 9:119-126.
Arriza JL, Fairman WA, Wadiche JI, Murdoch GH, Kavanaugh MP, Amara SG (1994) Functional comparisons of three glutamate transporter subtypes cloned from human motor cortex. J Neurosci 14:5559-5569.

Arriza JL, Eliasof S, Kavanaugh MP, Amara SG (1997) Excitatory amino acid transporter 5, a retinal glutamate transporter coupled to a chloride conductance. Proc Natl Acad Sci USA 94:4155-4160.

Back SA, Gan X, Li Y, Rosenberg PA, Volpe JJ (1998) Maturationdependent vulnerability of oligodendrocytes to oxidative stress-induced death caused by glutathione depletion. J Neurosci 18:6241-6253.

Baud O, Greene AE, Li J, Wang H, Volpe JJ, Rosenberg PA (2004) Glutathione peroxidase-catalase cooperativity is required for resistance to hydrogen peroxide by mature rat oligodendrocytes. J Neurosci 24:1531-1540.

Bergles DE, Jahr CE (1998) Glial contribution to glutamate uptake at Schaffer collateral-commissural synapses in the hippocampus. J Neurosci 18:7709-7716.

Bergles DE, Diamond JS, Jahr CE (1999) Clearance of glutamate inside the synapse and beyond. Curr Opin Neurobiol 9:293-298.

Bezzi P, Carmignoto G, Pasti L, Vesce S, Rossi D, Rizzini BL, Pozzan T, Volterra A (1998) Prostaglandins stimulate calcium-dependent glutamate release in astrocytes. Nature 391:281-285.

Bezzi P, Domercq M, Brambilla L, Galli R, Schols D, De Clercq E, Vescovi A, Bagetta G, Kollias G, Meldolesi J, Volterra A (2001) CXCR4-activated astrocyte glutamate release via TNFalpha: amplification by microglia triggers neurotoxicity. Nat Neurosci 4:702-710.

Bridges RJ, Stanley MS, Anderson MW, Cotman CW, Chamberlin AR (1991) Conformationally defined neurotransmitter analogues. Selective inhibition of glutamate uptake by one pyrrolidine-2,4-dicarboxylate diastereomer. J Med Chem 34:717-725.

Bridges RJ, Kavanaugh MP, Chamberlin AR (1999) A pharmacological review of competitive inhibitors and substrates of high-affinity, sodiumdependent glutamate transport in the central nervous system. Curr Pharm Des 5:363-379.

Chen W, Aoki C, Mahadomrongkul V, Gruber CE, Wang GJ, Blitzblau R, Irwin N, Rosenberg PA (2002) Expression of a variant form of the glutamate transporter GLT1 in neuronal cultures and in neurons and astrocytes in the rat brain. J Neurosci 22:2142-2152.

Chen W, Mahadomrongkul V, Berger UV, Bassan M, DeSilva T, Tanaka K, Irwin N, Aoki C, Rosenberg PA (2004) The glutamate transporter 
GLT1a is expressed in excitatory axon terminals of mature hippocampal neurons. J Neurosci 24:1136-1148.

Coco S, Verderio C, Trotti D, Rothstein JD, Volterra A, Matteoli M (1997) Non-synaptic localization of the glutamate transporter EAAC1 in cultured hippocampal neurons. Eur J Neurosci 9:1902-1910.

Conti F, DeBiasi S, Minelli A, Rothstein JD, Melone M (1998) EAAC1, a high-affinity glutamate tranporter, is localized to astrocytes and gabaergic neurons besides pyramidal cells in the rat cerebral cortex. Cereb Cortex $8: 108-116$

Danbolt NC (2001) Glutamate uptake. Prog Neurobiol 65:1-105.

Davis KE, Straff DJ, Weinstein EA, Bannerman PG, Correale DM, Rothstein JD, Robinson MB (1998) Multiple signaling pathways regulate cell surface expression and activity of the excitatory amino acid carrier 1 subtype of Glu transporter in C6 glioma. J Neurosci 18:2475-2485.

Dawson MR, Polito A, Levine JM, Reynolds R (2003) NG2-expressing glial progenitor cells: an abundant and widespread population of cycling cells in the adult rat CNS. Mol Cell Neurosci 24:476-488.

Deng W, Rosenberg PA, Volpe JJ, Jensen FE (2003) Calcium-permeable AMPA/kainate receptors mediate toxicity and preconditioning by oxygen-glucose deprivation in oligodendrocyte precursors. Proc Natl Acad Sci USA 100:6801-6806.

DeSilva TM, Kinney HC, Borenstein NS, Trachtenberg FL, Irwin N, Volpe JJ, Rosenberg PA (2007) The glutamate transporter EAAT2 is transiently expressed in developing human cerebral white matter. J Comp Neurol 501:879-890.

DeSilva TM, Billiards SS, Borenstein NS, Trachtenberg FL, Volpe JJ, Kinney HC, Rosenberg PA (2008) Glutamate transporter EAAT2 expression is up-regulated in reactive astrocytes in human periventricular leukomalacia. J Comp Neurol 508:238-248.

Domercq M, Sánchez-Gómez MV, Areso P, Matute C (1999) Expression of glutamate transporters in rat optic nerve oligodendrocytes. Eur J Neurosci 11:2226-2236.

Dowd LA, Coyle AJ, Rothstein JD, Pritchett DB, Robinson MB (1996) Comparison of $\mathrm{Na}^{+}$-dependent glutamate transport activity in synaptosomes, C6 glioma, and Xenopus oocytes expressing excitatory amino acid carrier 1 (EAAC1). Mol Pharmacol 49:465-473.

Espinosa de los Monteros A, Yuan J, McCartney D, Madrid R, Cole R, Kanfer JN, deVellis J (1997) Acceleration of the maturation of oligodendroblasts into oligodendrocytes and enhancement of their myelinogenic properties by a chemically defined medium. Dev Neurosci 19:297-311.

Fairman WA, Vandenberg RJ, Arriza JL, Kavanaugh MP, Amara SG (1995) An excitatory amino-acid transporter with properties of a ligand-gated chloride channel. Nature 375:599-603.

Fern R, Möller T (2000) Rapid ischemic cell death in immature oligodendrocytes: a fatal glutamate release feedback loop. J Neurosci 20:34-42.

Follett PL, Rosenberg PA, Volpe JJ, Jensen FE (2000) NBQX attenuates excitotoxic injury in developing white matter. J Neurosci 20:9235-9241.

Furness DN, Dehnes Y, Akhtar AQ, Rossi DJ, Hamann M, Grutle NJ, Gundersen V, Holmseth S, Lehre KP, Ullensvang K, Wojewodzic M, Zhou Y, Attwell D, Danbolt NC (2008) A quantitative assessment of glutamate uptake into hippocampal synaptic terminals and astrocytes: new insights into a neuronal role for excitatory amino acid transporter 2 (EAAT2). Neuroscience 157:80-94.

Furuta A, Rothstein JD, Martin LJ (1997) Glutamate transporter protein subtypes are expressed differentially during rat CNS development. J Neurosci 17:8363-8375.

Furuta A, Takashima S, Yokoo H, Rothstein JD, Wada K, Iwaki T (2005) Expression of glutamate transporter subtypes during normal human corticogenesis and type II lissencephaly. Brain Res Dev Brain Res 155:155-164.

Gallo V, Russell JT (1995) Excitatory amino acid receptors in glia: different subtypes for distinct functions. J Neurosci Res 42:1-8.

Gallo V, Zhou JM, McBain CJ, Wright P, Knutson PL, Armstrong RC (1996) Oligodendrocyte progenitor cell proliferation and lineage progression are regulated by glutamate receptor-mediated $\mathrm{K}^{+}$channel block. J Neurosci 16:2659-2670.

Gard AL, Pfeiffer SE, Williams WCI (1993) Immunopanning and developmental stage-specific primary culture of oligodendrocytes progenitors $(\mathrm{O} 4+\mathrm{GalC}-)$ directly from postnatal rodent cerebrum. Neuroprotocols 2:209-218

Garlin AB, Sinor AD, Sinor JD, Jee SH, Grinspan JB, Robinson MB (1995)
Pharmacology of sodium-dependent high-affinity L- $\left[{ }^{3} \mathrm{H}\right]$ glutamate transport in glial cultures. J Neurochem 64:2572-2580.

Gudz TI, Komuro H, Macklin WB (2006) Glutamate stimulates oligodendrocyte progenitor migration mediated via an $\alpha \mathrm{v}$ integrin/myelin proteolipid protein complex. J Neurosci 26:2458-2466.

Jain A, Mårtensson J, Stole E, Auld PA, Meister A (1991) Glutathione deficiency leads to mitochondrial damage in brain. Proc Natl Acad Sci U S A 88:1913-1917.

Káradóttir R, Cavelier P, Bergersen LH, Attwell D (2005) NMDA receptors are expressed in oligodendrocytes and activated in ischaemia. Nature 438:1162-1166.

Levine JM, Stincone F, Lee YS (1993) Development and differentiation of glial precursor cells in the rat cerebellum. Glia 7:307-321.

Li J, Lin JC, Wang H, Peterson JW, Furie BC, Furie B, Booth SL, Volpe JJ, Rosenberg PA (2003) Novel role of vitamin $\mathrm{k}$ in preventing oxidative injury to developing oligodendrocytes and neurons. J Neurosci 23:5816-5826.

Maragakis NJ, Dietrich J, Wong V, Xue H, Mayer-Proschel M, Rao MS, Rothstein JD (2004) Glutamate transporter expression and function in human glial progenitors. Glia 45:133-143.

McCarthy KD, de Vellis J (1980) Preparation of separate astroglial and oligodendroglial cell cultures from rat cerebral tissue. J Cell Biol 85:890-902.

Meucci O, Fatatis A, Holzwarth JA, Miller RJ (1996) Developmental regulation of the toxin sensitivity of $\mathrm{Ca}^{2+}$-permeable AMPA receptors in cortical glia. J Neurosci 16:519-530.

Micu I, Jiang Q, Coderre E, Ridsdale A, Zhang L, Woulfe J, Yin X, Trapp BD, McRory JE, Rehak R, Zamponi GW, Wang W, Stys PK (2006) NMDA receptors mediate calcium accumulation in myelin during chemical ischaemia. Nature 439:988-992.

Northington FJ, Traystman RJ, Koehler RC, Martin LJ (1999) GLT1, glial glutamate transporter, is transiently expressed in neurons and develops astrocyte specificity only after midgestation in the ovine fetal brain. J Neurobiol 39:515-526.

Oka A, Belliveau MJ, Rosenberg PA, Volpe JJ (1993) Vulnerability of oligodendroglia to glutamate: pharmacology, mechanisms, and prevention. J Neurosci 13:1441-1453.

Parpura V, Basarsky TA, Liu F, Jeftinija K, Jeftinija S, Haydon PG (1994) Glutamate-mediated astrocyte-neuron signalling. Nature 369:744-747.

Patneau DK, Wright PW, Winters C, Mayer ML, Gallo V (1994) Glial cells of the oligodendrocyte lineage express both kainate-and AMPApreferring subtypes of glutamate receptor. Neuron 12:357-371.

Pines G, Danbolt NC, Bjørås M, Zhang Y, Bendahan A, Eide L, Koepsell H, Storm-Mathisen J, Seeberg E, Kanner BI (1992) Cloning and expression of a rat brain L-glutamate transporter. Nature 360:464-467.

Pitt D, Nagelmeier IE, Wilson HC, Raine CS (2003) Glutamate uptake by oligodendrocytes: Implications for excitotoxicity in multiple sclerosis. Neurology 61:1113-1120.

Polito A, Reynolds R (2005) Reynolds R NG2-expressing cells as oligodendrocyte progenitors in the normal and demyelinated adult central nervous system. J Anat 207:707-716.

Puchalski RB, Louis JC, Brose N, Traynelis SF, Egebjerg J, Kukekov V, Wenthold RJ, Rogers SW, Lin F, Moran T (1994) Selective RNA editing and subunit assembly of native glutamate receptors. Neuron 13:131-147.

Regan MR, Huang YH, Kim YS, Dykes-Hoberg MI, Jin L, Watkins AM, Bergles DE, Rothstein JD (2007) Variations in promoter activity reveal a differential expression and physiology of glutamate transporters by glia in the developing and mature CNS. J Neurosci 27:6607-6619.

Rosenberg PA, Aizenman E (1989) Hundred-fold increase in neuronal vulnerability to glutamate toxicity in astrocyte-poor cultures of rat cerebral cortex. Neurosci Lett 103:162-168.

Rosenberg PA, Amin S, Leitner M (1992) Glutamate uptake disguises neurotoxic potency of glutamate agonists in cerebral cortex in dissociated cell culture. J Neurosci 12:56-61.

Rosenberg PA, Dai W, Gan XD, Ali S, Fu J, Back SA, Sanchez RM, Segal MM, Follett PL, Jensen FE, Volpe JJ (2003) Mature myelin basic proteinexpressing oligodendrocytes are insensitive to kainate toxicity. J Neurosci Res 71:237-245.

Rothstein JD, Martin L, Levey AI, Dykes-Hoberg M, Jin L, Wu D, Nash N, Kuncl RW (1994) Localization of neuronal and glial glutamate transporters. Neuron 13:713-725.

Salter MG, Fern R (2005) NMDA receptors are expressed in developing oligodendrocyte processes and mediate injury. Nature 438:1167-1171. 
Schlag BD, Vondrasek JR, Munir M, Kalandadze A, Zelenaia OA, Rothstein JD, Robinson MB (1998) Regulation of the glial $\mathrm{Na}^{+}$-dependent glutamate transporters by cyclic AMP analogs and neurons. Mol Pharmacol 53:355-369.

Schulz JB, Lindenau J, Seyfried J, Dichgans J (2000) Glutathione, oxidative stress and neurodegeneration. Eur J Biochem 267:4904-4911.

Shimamoto K, Lebrun B, Yasuda-Kamatani Y, Sakaitani M, Shigeri Y, Yumoto N, Nakajima T (1998) DL-threo-beta-benzyloxyaspartate, a potent blocker of excitatory amino acid transporters. Mol Pharmacol 53: 195-201.

Storck T, Schulte S, Hofmann K, Stoffel W (1992) Structure, expression, and functional analysis of a $\mathrm{Na}^{+}$- dependent glutamate/aspartate transporter from rat brain. Proc Natl Acad Sci U S A 89:10955-10959.

Swanson RA, Liu J, Miller JW, Rothstein JD, Farrell K, Stein BA, Longuemare MC (1997) Neuronal regulation of glutamate transporter subtype expression in astrocytes. J Neurosci 17:932-940.

Talos DM, Fishman RE, Park H, Folkerth RD, Follett PL, Volpe JJ, Jensen FE (2006a) Developmental regulation of alpha-amino-3-hydroxy-5methyl-4-isoxazole-propionic acid receptor subunit expression in forebrain and relationship to regional susceptibility to hypoxic/ischemic injury. I. Rodent cerebral white matter and cortex. J Comp Neurol 497:42-60.

Talos DM, Follett PL, Folkerth RD, Fishman RE, Trachtenberg FL, Volpe JJ, Jensen FE (2006b) Developmental regulation of alpha-amino-3hydroxy-5-methyl-4-isoxazole-propionic acid receptor subunit expression in forebrain and relationship to regional susceptibility to hypoxic/ ischemic injury. II. Human cerebral white matter and cortex. J Comp Neurol 497:61-77.
Tanaka K, Watase K, Manabe T, Yamada K, Watanabe M, Takahashi K, Iwama H, Nishikawa T, Ichihara N, Kikuchi T, Okuyama S, Kawashima N, Hori S, Takimoto M, Wada K (1997) Epilepsy and exacerbation of brain injury in mice lacking the glutamate transporter GLT-1. Science 276:1699-1702.

Wang GJ, Chung HJ, Schnuer J, Pratt K, Zable AC, Kavanaugh MP, Rosenberg PA (1998) High affinity glutamate transport in rat cortical neurons in culture. Mol Pharmacol 53:88-96.

Wang H, Li J, Follett PL, Zhang Y, Cotanche DA, Jensen FE, Volpe JJ, Rosenberg PA (2004) 12-Lipoxygenase plays a key role in cell death caused by glutathione depletion and arachidonic acid in rat oligodendrocytes. Eur J Neurosci 20:2049-2058.

Yamada K, Watanabe M, Shibata T, Nagashima M, Tanaka K, Inoue Y (1998) Glutamate transporter GLT-1 is transiently localized on growing axons of the mouse spinal cord before establishing astrocytic expression. J Neurosci 18:5706-5713.

Yoshioka A, Hardy M, Younkin DP, Grinspan JB, Stern JL, Pleasure D (1995) $\alpha$-Amino-3-hydroxy-5-methyl-4-isoxazolepropionate (AMPA) receptors mediate excitotoxicity in the oligodendroglial lineage. J Neurochem 64:2442-2448.

Yuan X, Eisen AM, McBain CJ, Gallo V (1998) A role for glutamate and its receptors in the regulation of oligodendrocyte development in cerebellar tissue slices. Development 125:2901-2914.

Zerangue N, Kavanaugh MP (1996) Interaction of L-cysteine with a human excitatory amino acid transporter. J Physiol 493:419-423.

Ziskin JL, Nishiyama A, Rubio M, Fukaya M, Bergles DE (2007) Vesicular release of glutamate from unmyelinated axons in white matter. Nat Neurosci 10:321-330. 